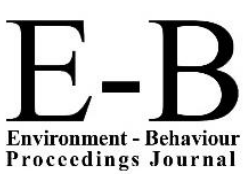

\title{
AicE-Bs2016Edinburgh
}

$7^{\text {th }}$ Asia-Pacific International Conference on Environment-Behaviour Studies, St Leonard Hall, Edinburgh University, United Kingdom, 27-30 July 2016

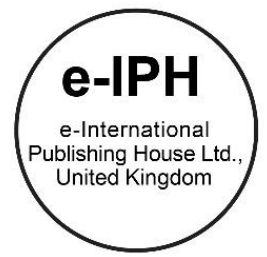

\section{Flexible Schools? A Review of School Design in Scotland}

\author{
Nik Farhanah Nik Azhari ${ }^{*}$, Fiona McLachlan ${ }^{1}$
}

${ }^{1}$ School of Architecture and Landscape Architecture, Edinburgh College of Art, The University of Edinburgh, Edinburgh, Scotland, United Kingdom

\begin{abstract}
Flexible is a common term used in the built environment, especially relating to current and future design. However, individuals will define the term in different ways in relation to their context. In school design, there are various interpretations and applications of 'flexible' terminology. The objective of this paper is to scrutinize the term flexible by reviewing its application primarily in Scottish Government publications relating to school design. This paper aims to generate constructive reflection for those involved in school design, directly and indirectly, so they can respond effectively to the question: What does 'flexible' mean in a school design context?

(C) 2016. The Authors. Published for AMER ABRA by e-International Publishing House, Ltd., UK. This is an open access article under the CC BYNC-ND license (http://creativecommons.org/licenses/by-nc-nd/4.0/).

Peer-review under responsibility of AMER (Association of Malaysian Environment-Behaviour Researchers), ABRA (Association of Behavioural Researchers on Asians) and CE-Bs (Centre for Environment-Behaviour Studies), Faculty of Architecture, Planning \& Surveying, Universiti Teknologi MARA, Malaysia..
\end{abstract}

Keywords: Flexible; School Design; Architectural Context; Operational Context.

\section{Introduction}

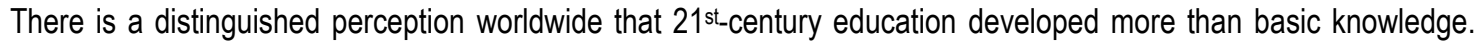
New schools introduce problem-solving skills, social and self-directional learning, with innovative tools of information and communication technologies (Pearlman, 2008). For that reason, this has led to the emergence of major school building programs worldwide as many nations began to reassess their national curricula. Australia, for example, was committed to constructing and refurbishment of their school infrastructure and learning environments through the $\$ 16.2$ billion Building the Education Revolution (BER) program (Australian Government, 2009). In England, the $£ 55$ billion investment of Building Schools for the Future (BSF) program had reflected UK Government's serious investment to improve every secondary school in the country (Public Accounts Committee, 2009). Both nations are

\footnotetext{
${ }^{*}$ Corresponding author. Tel.: +447519293964

E-mail address: nikfarhanah.azhari@gmail.com
}

2398-4287 @ 2016. The Authors. Published for AMER ABRA by e-International Publishing House, Ltd., UK. This is an open access article under the CC BY-NC-ND license (http://creativecommons.org/licenses/by-nc-nd/4.0/).

Peer-review under responsibility of AMER (Association of Malaysian Environment-Behaviour Researchers), ABRA (Association of Behavioural Researchers on Asians) and CE-Bs (Centre for Environment-Behaviour Studies), Faculty of Architecture, Planning \& Surveying, Universiti Teknologi MARA, Malaysia.

DOI: http://dx.doi.org/10.21834/e-bpj.v1i4.178 
highly dedicated to creating new learning spaces which address student needs, besides Portugal, Finland and the Netherlands (Loughlin, 2013). Schools are responding to these initiatives to improve the quality of teaching and learning. In 2010, Scotland underwent one of the biggest reforms of its education system in history. 'A coherent, more flexible and enriched Curriculum for Excellence was launched to uplift the learning experience for children and young people' (Education Scotland, 2008). The new curriculum leads towards the subsistence of a massive school building programme, from improving school estates, refurbishing existing property, up to building new schools. The Government has vowed to improve the entire school's estate that remains in poor or bad 'condition' or 'suitability' (Scottish Government, 2009). A summary statistics for schools in Scotland reported that out of 2555 total number of schools in Scotland, approximately 607 schools were rebuilt or have been substantially refurbished since 2007(Scottish Government, 2015). The positive indicator shows the Government's serious ambition to provide the best learning and experience for every child and young people in Scotland.

\section{Literature Review}

\subsection{Curriculum for Excellence - a Stimulus for Scotland's Schools}

The implementation of the Curriculum for Excellence has raised the importance of the quality of physical design and use in schools (Scottish Government and COSLA, 2009). 'New schools are now expected to be better in design with extensively considered environments that inspire learning and experiences' (Scottish Government, 2009). Children and young people in new schools have the opportunity to experience learning as a whole throughout their school years (Education Scotland, 2008). The Curriculum for Excellence inspires learning beyond conventional spaces and subjects in schools and furthermore acknowledges community collaboration. Learning is now boundless and no longer restricted to the classroom nor any other school spaces. Curriculum for Excellence is flexible, and aims at improving pupil's overall experiences, skills as well as the achievement (HMIE, 2003). Such flexibility is important, and influence learning. Learning and Teaching Scotland (2003), defines curriculum flexibility as the strategies schools and local authorities implement when designing a customised curriculum, which considers schools' local circumstances, students' needs and requirements, as well as the expectations of learners, stakeholders and society in general. For that reason, Scotland's schools are now anticipated to deliver wide-ranged of education to all learners. 'The purpose, functions, design and the way school spaces are used have gradually changed as a result' (Scottish Government and COSLA 2009).

\subsection{Flexible School Design}

The term 'flexible' has been consistently cited in most evidence-based reviews and design guidelines for future schools either locally or elsewhere. The term 'flexible' however is still very broad, particularly in the context of school design. It is uncertain whether flexibility in school design signifies a flexible environment, space or the classroom itself. It is an essential concern whether schools should be flexible especially in accommodating $21^{\text {st-century }}$ teaching and learning. Traditional models of school design are believed to be no longer conducive' (Pearlman, 2011), and differs with the design features of 21 st-century schools. New school design places students and teachers at the centre of the educational process, and facilitates innovative pedagogical methods (OECD, 2006; Pearlman, 2008). It is a huge challenge to design schools that could fulfil the demands of the new knowledge society. According to Van de Brande (1993), 'there must be more flexibility to meet the needs of the learner, through adaptability to different learner needs, learning patterns and settings, and media combinations'. Schools need to be able to 'flex' in response to future changes in the scale, nature of demand and usage (Scottish Government \& 
COSLA, 2009). Sigurðardóttir and Hjartarson (2011) mentioned that the demand for flexibility in school design applies to many different features of a building such as spaces and environment for various group sizes and learning styles, dynamic boundaries and the ability to change facilities according to pedagogical needs and ideas. According to Building Futures (2004), among the factors to consider for school design to fulfill new educational or organisational ideas is adaptability and expansion of space, as well as location and relationships of facilities. Flexibility can be affected by area or width of room if it is too small to allow a variety of layouts and activities; awkward shapes; inappropriate or fixed furniture or equipment (Building Futures, 2004).

\section{Methodology}

\subsection{Literature Search}

The literature search was systematically initiated to ensure the breadth of the search within all available resources. However, this paper emphasizes primarily on Scottish Government publications. The search commenced by accessing the official Scottish Government website at www.gov.scot. In obtaining topics on school design, the search only retrieves the keyword 'school buildings' under the topic of Education and Training. Undoubtedly, there are numerous publications on schools. However, most publications related to school design specifically are listed under the topics of (i) Strategy, and (ii) Design Guidance.

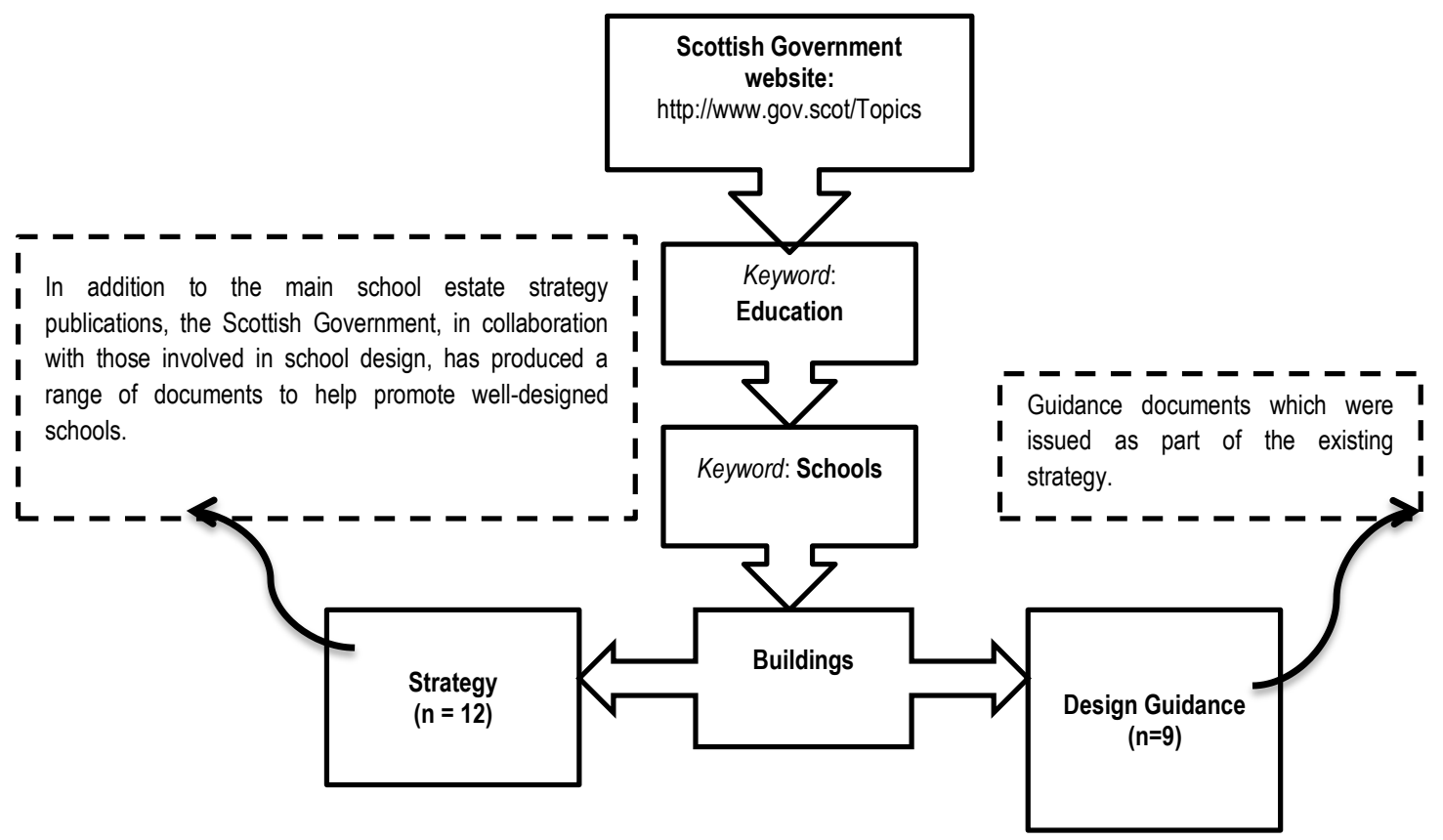

Figure 1. A flow diagram illustrating the filtering process for relevancy before being reviewed for application of flexible terminology. 


\subsection{Relevant Literature Extraction}

Table 1. Flexible terminology application in school design guidance and strategy found in Scottish Government Publications (Author,2016)

\begin{tabular}{|c|c|c|c|c|c|c|c|c|c|c|c|c|c|c|c|c|c|c|c|}
\hline & & & 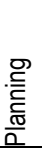 & 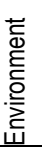 & $\begin{array}{l}\overline{8} \\
\frac{0}{1} \\
\bar{c}\end{array}$ & 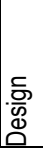 & 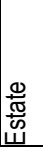 & 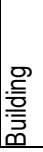 & 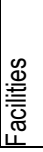 & 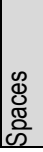 & $\frac{\infty}{\bar{N}}$ & 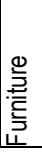 & 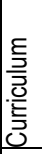 & 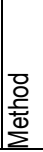 & $\begin{array}{l}\frac{E}{0} \\
\frac{\omega}{\omega} \\
\omega \\
\omega\end{array}$ & 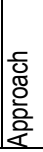 & 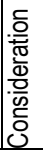 & 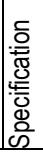 & 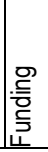 \\
\hline Topic & Publications & Year & \multicolumn{10}{|c|}{ Architectural Context } & \multicolumn{7}{|c|}{ Operational Context } \\
\hline \multirow{12}{*}{$\begin{array}{l}\text { ब্ষ } \\
\text { कँ } \\
\text { क }\end{array}$} & $\begin{array}{l}\text { Determining Primary School } \\
\text { Capacity }\end{array}$ & 2014 & & & & & & & & & & & & - & & - & & & \\
\hline & $\begin{array}{l}\text { Building Better Schools: } \\
\text { Investing in Scotland's } \\
\text { Future }\end{array}$ & 2009 & $\bullet$ & & $\bullet$ & $\bullet$ & $\bullet$ & $\bullet$ & $\bullet$ & $\bullet$ & & & & & & - & & & $\bullet$ \\
\hline & Suitability Core Fact & 2008 & & & & & & & & & & & & & & & & & \\
\hline & Condition Core Fact & 2007 & प & [ & [ & 口 & [ & [ & [ & [ & [ & [ & & & & & & & \\
\hline & $\begin{array}{l}\text { *School Design: Optimizing } \\
\text { the internal environment }\end{array}$ & 2007 & [ & [ & [ & [ & [ & [ & [ & $\bullet$ & [ & [ & & & & & & & \\
\hline & $\begin{array}{l}\text { *Post Occupancy Evaluation } \\
\text { Workshop }\end{array}$ & 2005 & [ & [ & [ & [ & [ & [ & [ & [ & [ & [ & & $\bullet$ & & & & & $\bullet$ \\
\hline & $\begin{array}{l}{ }^{*} \text { Post Occupancy Evaluation } \\
\text { - Braes High School, Falkirk }\end{array}$ & 2005 & [ & [ & [ & [ & [ & [ & [ & [ & [ & [ & & & & & & & \\
\hline & Output Specification & 2004 & [ & [ & [ & [ & [ & [ & [ & [ & [ & [ & & & & & & $\bullet$ & \\
\hline & Option Appraisal & 2004 & [ & [ & [ & [ & [ & $\bullet$ & [ & [ & [ & [ & & & & & & & \\
\hline & Evaluation & 2004 & [ & [ & [ & 口 & [ & [ & - & - & - & 口 & & & & & & & \\
\hline & $\begin{array}{l}\text { Managing Schools During } \\
\text { Construction Projects }\end{array}$ & 2004 & [ & [ & [ & [ & [ & [ & [ & [ & [ & [ & & & & & - & & \\
\hline & *Sustainability & 2004 & [ & [ & [ & [ & [ & [ & [ & $\bullet$ & [ & [ & $\bullet$ & & & & & & \\
\hline \multirow{5}{*}{ 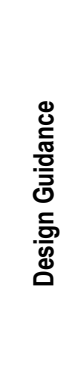 } & Building Excellence & 2007 & • & $\cdot$ & [ & [ & [ & [ & $\bullet$ & $\bullet$ & प & - & $\bullet$ & & $\bullet$ & & & & \\
\hline & Senses of Place & 2006 & [ & [ & [ & [ & [ & $\bullet$ & [ & $\bullet$ & [ & $\bullet$ & & & $\bullet$ & $\bullet$ & [ & & \\
\hline & $\begin{array}{l}\text { Research on acoustic } \\
\text { design in Scottish primary } \\
\text { schools }\end{array}$ & 2005 & [ & [ & [ & [ & [ & [ & [ & [ & [ & [ & & $\bullet$ & & & & & \\
\hline & $\begin{array}{l}\text { Design and Construction of } \\
\text { Sustainable Schools } \\
\text { Volume } 1\end{array}$ & 2005 & $\bullet$ & [ & $\bullet$ & [ & [ & [ & [ & $\bullet$ & [ & [ & & & & & & & \\
\hline & $\begin{array}{l}\text { Design and Construction of } \\
\text { Sustainable Schools } \\
\text { Volume } 2 \\
\end{array}$ & 2005 & [ & [ & [ & [ & [ & [ & [ & [ & [ & [ & & & - & & & & \\
\hline
\end{tabular}

*Publications found in both topics of Strategy and Design Guidance.

\section{Discussion and Findings}

The application of the flexible terminology is reviewed in Scottish Government publications under the topic (i) Strategy, and (ii) Design Guidance. The Strategy is an addition to the main School Estate Strategy publications by the Scottish Government collaborating with those involved in school design. Design Guidance, are the guideline documents, which were issued as part of the existing School Estate Strategy. Various publications since the year 
2004 up to 2014 have shown a regular application of the term flexible within two distinctive contexts. Dey (2001) defined context as 'any information that can be used to characterise the situation of an entity, which can either be a person, place, or object that is considered relevant to the interaction between a user and application'. Thus, the next segment of this paper discusses two contexts, which consists of Architectural Context, and Operational Context, with their entities most applied to flexible terminology.

\subsection{Architectural Context}

Architectural context includes external influences on an object, either physical or non-physical. In the case of flexible terminology within an architectural context, the elements are wide-ranging from the macro to micro level. The term flexible is associated with planning at the macro level and flexible furniture at the micro level. The terminology is commonly applied within the architectural context in both Scottish Government's school strategy or the design guidance. As shown in Table 1, Building Better Schools: Investing in Scotland's Future by the Scottish Government and COSLA (2009) has regularly mentioned the terminology throughout the publications. Reflecting the government's vision and aspiration, the future school estate is regularly associated with flexible terminology. In school design, space is the most commonly associated with flexibility, both externally and internally. This is anticipated within the current Curriculum for Excellence, whereby learning may take place anywhere suit the learners. School grounds are to be as flexible as any formal teaching and learning spaces.

\subsection{Operational Context}

Operational context is the external environment that influences its operation. Throughout this paper, operational context denotes the factor, which influences the process of managing schools. Table 1 illustrates the various entities of operational context affecting school management which vary from flexible curriculum, flexible approach and to the extent of flexible funding. The regular distribution of operational context depicts the essentials of flexibility in nonarchitectural context. Other words, management of the school must be as flexible as the school itself to coincide with the aim of Curriculum for Excellence.

\section{Conclusion}

It is evident on the topics of school design in Scotland that the term flexible is commonly applied. The term flexible is regularly associated with both architectural and operational context of school design. The commonality depicts the needs, especially for future schools. Therefore, it is essential to appropriately define the terminology for better implementation and clearer expectation. Undeniably, the terminology should be well reviewed and define through academic literature, as well as other valid professional resources. However, in understanding the extensiveness of the terminology, it is also substantial to inquire how the end users define the term flexible. Further research is recommended in outlining the flexibility of school design among the teachers and pupils in schools.

\section{References}

Australian Government. (2009). Building the Education Revolution: National Coordinator's Implementation Report. 
Building Futures. (2004). 21st Century Schools: Learning Environments of the Future.

Dey, A. K. (2001). Understanding and Using Context. Personal and Ubiquitous Computing, 5(1), 4-7. http://doi.org/10.1007/s007790170019

Education Scotland. (2008). Building the Curriculum 3: A Framework for Learning and Teaching. Edinburgh.

HMIE. (2003). Curriculum Flexibility: How good is our school? Improving Scottish Education.

Learning and Teaching Scotland. (2003). Focusing on Curriculum Flexibility in Secondary Schools: A Paper for Professional Reflection.

Loughlin, J. (2013). How photography as field notes helps in understanding the building the education revolution. Australian Educational Researcher, 40(5), 535-548. http://doi.org/10.1007/s13384-013-0112-1

OECD. (2006). 21st Century Learning Environments. Retrieved from http://www.oecdbookshop.org/oecd/display.asp?sf1=identifiers\&lang=EN\&st1=952006021p1

Pearlman, B. (2008). Designing New Learning Environments to Support 21st Century Skills. 21st Century Skills, 116-147. Retrieved from http://www.designshare.com/images/chap6_designing_new_learning_environments.pdf

Pearlman, B. (2011). School Structures that Support 21 st Century Learning. Hanover Research: District Administration Practice. Washington DC. Retrieved from http://files.solutiontree.com/pdfs/Reproducibles_21CS/chap6_designing_new_learning_environtments.pdf

Public Accounts Committee. (2009). The Building Schools for the Future programme: Renewing the secondary school estate.

Scottish Government. (2015). Summary Statistics for Schools in Scotland (Vol. 6).

Scottish Government and COSLA. (2009). Building Better Schools: Investing in Scotland's Future.

Sigurðardóttir, A. K., \& Hjartarson, T. (2011). School buildings for the 21st century. Some features of new school buildings in Iceland. Centre for Educational Policy Studies Journal, 1(2), 25-44.

Van de Brande, L. (1993). Flexible and distance learning. Chichester: John Wiley. 